\title{
Integrating academic reading and writing skills development with core content in science and engineering
}

\author{
Kathryn J. Amos \\ University of Adelaide, Australia \\ Ursula McGowan \\ University of Adelaide, Australia
}

\begin{abstract}
This paper presents the application of genre pedagogy as an approach to teaching academic reading and writing skills development to a class of undergraduate engineering students. This approach was designed so that it may be applied by core subject teachers in courses with students who typically do not engage well with these aspects of their studies. Our focus was specifically on the 'bigger picture' of writing skills development by encouraging students to learn how to analyse for themselves a particular genre from their own discipline, and how to use this knowledge to develop an appropriately academic style in writing their own essay.
\end{abstract}

Our approach involved combining the expertise of subject teacher and linguist in running four workshops in class time during the first half of a semesterised course. These workshops had associated homework tasks, designed incrementally to contribute to students' understanding and application of the skills they need for academic writing. These were followed by the submission of a written report on the topics covered during the first six weeks of the semester, and was of direct relevance to their degree major. Assessment criteria focused on both technical content and academic literacy. With this integrated approach to literacy and content development it was intended to engage traditionally resistant students with the development of their academic language skills, and also to model a possible approach for the engagement of STEM academics in fostering this academic literacy development. Student participants in this programme agreed that this strategy improved both their writing skills and their understanding of course content.

Keywords: STEM; integrated academic language development; genre-analysis; reading; academic writing; engineering; science. 


\section{Introduction}

A commonly reported problem from employers is that the writing of engineering graduates is not of sufficient standard (e.g. Berthouex, 1996; Oakley et al., 1999). The incorporation of writing within engineering courses is not a new topic of discussion, with published articles focusing on this matter dating from 1911 (references cited within Wheeler and McDonald, 2000). Despite this, the development of student writing skills in some discipline areas, including engineering, is still a challenge (Cismas, 2010). This is in part due to a typical lack of engagement with writing by students in the sciences, technology, engineering and mathematics (STEM) and in part also to a lack of engagement of STEM lecturers with the development of writing skills in students. It is often perceived that to focus on transferable skills development in students, some of the core content teaching and learning needs to be sacrificed. However, it has been shown that development of academic reading and writing skills can also enhance student understanding of core content (Wheeler and McDonald, 2000).

This paper presents an application of genre pedagogy, which involves a cyclical process of analysing and discussing examples of good writing in order to assist students in learning their structure and language, and then applying this to their own writing, first in groups and then individually (e.g. Disadvantaged Schools Program, 1988). A modified approach of this methodology was applied that could be delivered in a limited amount of time available within mainstream classes, integrated into an undergraduate subject. Here the writing skills development was combined with increasing student understanding of technical course content and offered to the whole class.

We use the word 'development' carefully; it is perhaps self-evident that the development of any skill requires practice, rather than students simply being told what they should do (e.g. Biggs, 1999). Our approach, patterned on the genre pedagogy approach cited above, involved the teaching of principles and techniques, followed by analysis of examples of the target genre ('modelling'), group practice ('joint construction') within class, the encouragement of subsequent practice by students in their own time, and finally the 'individual construction' of an assignment for assessment.

Our focus was specifically on the 'bigger picture' of writing skills development: on how students can 'unpack' densely written academic texts $(V e n t o l a, 1996)$ by analysing the 
structure of a report, the structure of content in paragraphs, the language choices at various stages; and finally how to use all of these analyses as models to advance their own writing skills. We purposefully avoided any focus on traditional grammatical terminology. Our work is based on the extensive theory and practices of the systemic functional linguistic movement's early implementation in the Disadvantaged Schools Project (Martin, 1989; 1997) as well as the work in English for specific purposes by Swales (1990) in higher degree thesis writing; and it also draws on two practical textbooks that develop stages of an experimental research paper by systematic modelling of structure and language choices found in published research papers (Weissberg and Buker, 1990; Cargill and O'Connor, 2009).

With our approach, instead of instructing students about correct sentences, we taught them how to analyse for themselves a particular genre from their own discipline and how to imitate the structure and style of writing that is appropriate for the context, and to do this without inadvertently plagiarising. The background and justification for these different facets of the study are explained in greater detail below.

\section{Aims}

In the adaptation of genre pedagogy to teaching integrated academic language skills with course content, our aims related to both the development of student reading and writing skills, and to student learning of core content. The aims were to:

1. Develop students' academic reading and writing skills, through providing students with specific tools for reading and writing that they can apply in the future.

2. Better engage students with course content.

3. Improve students' integration of the technical content taught over the first six weeks of the course.

\section{An additional challenge: engaging engineering students with geoscience course content}

The latter two aims of this study warrant further introduction. The course focused on in this case-study teaches Sedimentology and Stratigraphy, i.e. geoscience subjects, to second 
year Petroleum Engineering students. The course includes the application of qualitative geological concepts to data, often with multiple possible solutions to a problem. Students need to be able to visualise landscapes and sub-surface sedimentary deposits that vary in three-dimensional space and in time. This differs substantially from many of the subject areas in which engineering students in this programme typically excel, such as maths and physics, where problem-solving frequently relies on quantitative methods. Many students have said that they struggle to understand or excel at the content of this course compared with their other courses. One consequence of this is that some of those students do not engage with the course material as well as they could and are more likely to revise specific tasks set during the course in isolation, rather than developing their learning through integrating different aspects of the content as the course develops.

\section{An integrated approach to skills development}

A number of different teaching approaches have been applied within tertiary education for the development of transferable skills. Chadha and Nicholls (2006) divide these into three distinct categories: embedding, integrating, and bolting-on; where a distinction is made between 'embedding' (no direct reference made to skills development within the core teaching of a course) and 'integrating' (direct reference is made to skills development). Bolting-on (sometimes described as 'parallel' or 'stand-alone' development, e.g. Drummond et al., 1998) describes the development of skills independently from the core discipline.

It has been suggested that, despite some advantages, 'embedded' skills development (in the sense used by Chadha and Nicholls, 2006) is less effective than when development of transferable skills is explicitly mentioned to students (Mottershead and Suggitt, 1996) and indeed named for students as learning objectives. This is supported by the findings of a study conducted by Kemp and Seagraves (1995) in which a high percentage of students at the end of their course did not feel that they had received help in the development of skills that the lecturers had stated that they were developing in an embedded manner. At the other end of the spectrum, the teaching of transferable skills in a bolt-on manner may result in students failing to understand the academic value of these skills; it is argued that core content and skills development should be integrated, and that skills development should be discipline-orientated (e.g. Kemp and Seagraves, 1995; Drummond et al., 1998; Atlay and Harris, 2000). Effective skills development relies on the provision of 
opportunities for students to practise skills with support and guidance in a way that encourages strategies for development to be constructed (Drummond et al., 1998). It has been proposed that inclusion of skills development into the curriculum provides an 'explicit pedagogy for inclusion and access' for all (Cope and Kalantzis, 1993, p.64; McGowan, 2010).

Wingate (2006, p.459) uses the term 'embedding' but extends it to address 'the complexity of skills in an inclusive and holistic manner by providing learning opportunities for all students progressively throughout the degree course'. She dismisses this, deeming its realisation to be impractical, since it would 'require an institutional approach', and that it would be 'especially unlikely that research-intensive universities, which attract a large percentage of high-achieving 'traditional' students, will see the need to make such a commitment to student learning'. She concludes that more effective support for student learning than that offered in a bolt-on format can be achieved without wide-ranging institutional changes, if more academic staff promote student skills development 'within their regular teaching' (Wingate, 2006, p.467). It is on this basis that an 'integrated' approach was implemented here.

\section{Unpacking densely written academic text}

Academic writing typically uses very formal language, and is generally more densely 'packed' than informal language (Halliday, 1985; Halliday and Hasan, 1985; Martin, 1997). Typically, the more densely-packed a text is with information, the more difficult it is to read, particularly for students new to the disciplinary content or students for whom English is an additional language (EAL). Informal language, such as the language of conversations, presents information in ways that can be less abstract, and therefore may be more easily understood. In order to help themselves make sense of densely written academic text, students need to 'unpack' it by converting abstract nouns into a more conversational form (McGowan, 2005). Taking students through the process of unpacking excerpts from a model academic text will assist them in their reading of discipline-specific articles, and can then be used to help them tackle the process of writing academically. They can do this by learning how to follow the process in reverse, and re-packing by converting information and ideas from an informal to a more formal style (Ventola, 1996). 


\section{'Harvesting' language}

A technique that can be taught to students which will assist them as they learn to write in a more densely-written academic style is that of making use of well written models for 'harvesting language' (McGowan, 2008; 2010), or purposefully making use of 'borrowed' language (Pennycook, 1996). These metaphors both describe the language learning strategy enabled by the tool of genre analysis, which involves the active development of an awareness of the structures and language patterns used in a particular discipline and for specific assignments (McGowan, 2005). In order to learn the technique of 'harvesting' academic language, students are encouraged to analyse excerpts from a model text (e.g. a published article from their academic discipline) and identify commonly used phrases that are appropriate to be used in their own writing. The use of genre analysis techniques in assisting student writing skills development provides a means by which students can acquire the structure and language that characterise their academic discipline at a faster rate than they otherwise are likely to achieve.

\section{Method}

\section{Development of our approach}

In preparation for integrating the academic writing development component into the curriculum, the existing course content and methods of assessment were reviewed. In the previous year (2010), the course assessment comprised $40 \%$ from coursework and $60 \%$ from the end-of-semester exam. The coursework component consisted of several assessed data-interpretation exercises and two short (two-page) fieldtrip reports, submitted throughout the semester.

It was decided that all aims of this project could be met by the introduction of a series of inclass workshops and 'homework tasks', culminating in the submission of a substantial piece of written assessment. The homework tasks were not assessed, but feedback was provided. The submission of these tasks was not mandatory, but was encouraged by giving students a small percentage of the final course mark for their submission. The new material presented during the workshops and used in the homework tasks would have a focus on both academic reading and writing skills and on course content. In addition to the stated aims, it was also expected that, through writing about course content in this way, students would develop a deeper and more thorough understanding of subject material. 
This integrated approach was designed to encourage students to engage with both the workshops and homework tasks, so that their submitted written assignments would benefit from being developed over a significant part of the semester.

The composition of the final grade for the course in 2011 was 35\% from coursework, 50\% from the final exam, and 15\% from the new written assignment. The rationale behind this change to assessment weighting was that $15 \%$ of a final course grade would be significant enough to emphasise its importance and to engage those students that are more motivated by assessment than course content. The assignment length was around 10003000 words, however, students were told:

The actual length of this written assignment is less important than the structure, referencing and content. Use the assessment criteria...as a guide to judge whether you have done enough to fulfil the criteria. However, l'd recommend that you aim for between 1000-3000 words.

Selection of the assignment title as 'Sedimentologic Controls on Reservoir Quality' was done specifically with the aims to better engage students with course content and to improve students' integration of technical content in mind. This title emphasises the impact of the course content on something that is obviously of relevance to petroleum engineers (the factors that influence the potential volume and flow of hydrocarbons in a reservoir rock). This focus also provides students with a direct way of seeing the links between and importance of the different topics taught during the first six weeks of the course.

At the conclusion of the final workshop, the aims and content of the approach were summarised for students in a handout, ending with the following statement:

What we have been doing deliberately here is what people learn to do gradually, unconsciously: by absorbing BOTH the content AND the language of their readings, they begin to re-use the structures and ways of writing they are exposed to. By doing this process consciously and deliberately, you can help yourself and accelerate your academic language development. 


\section{The workshops}

Four Academic Language Development (ALD) workshops were run, each given one hour of lecture time (Table 1). These were spread out over six weeks of the semester and were jointly run by the academic developer/linguist (McGowan) and the course lecturer (Amos), taking turns in leading students through the linguistic exercise and the technical content. These workshops each involved some explanation of the aspect of academic writing being focused on, followed by a presentation of a demonstration example, and then students working through similar exercises during the workshop. Both the examples provided and practical exercises made use of the two selected journal articles that were used during each of the four workshops.

\section{Selection of the example articles}

Article selection was a non-trivial process, since it was determined in advance that the articles to be used should ideally fulfil the following criteria:

1. Content covers material taught during the first six weeks of the course.

2. Content includes an evaluation of reservoir quality (the focus of the set assignment).

3. The article should have a petroleum-industry focus, to better engage the students.

4. The article needs to be well written and structured (both as a whole and at paragraph level).

5. The article should not be overly technical, as too much advanced technical geoscience content might disengage engineering students.

6. The article should not be too long, as this might overwhelm and/or disengage students.

A substantial search through published articles was conducted and no paper was found that we felt met all of the desired criteria. The article selected was: 'Depositional Controls on Reservoir Properties in a Braid-Delta Sandstone, Tirrawarra Oil Field, South Australia' (Hamlin et al., 1996), published in the American Association of Petroleum Geologists Bulletin. This met the first four criteria, but was initially considered to contain too much technical detail and to be too long ( 5500 words) for encouraging student engagement. However, it was deemed beneficial that this article focused on a local (South Australian) oil field, and that the research was funded by a key locally-based company that students 
would be familiar with. We also provided students with a second article, and used some excerpts from this in the workshops as well: 'Sandstone Reservoir Quality Prediction: The State of the Art' (Ajdukiewicz and Lander, 2010; also published in the American Association of Petroleum Geologists Bulletin and authored by industry scientists).

\section{Workshop 1}

This introduced our approach to the class and focused on the concept of unpacking academic language, i.e. 'translating' excerpts of the selected academic articles into spoken language. Students worked through examples of this and the significant differences between these two modes of communication were discussed.

\section{Workshop 2}

This workshop focused on analysis of one of the chosen articles (Hamlin et al., 2006) to identify its structure and how the title related to this. We then discussed with the class how they could start planning their assignment content based on its title. In a second exercise, the structure of the Introduction section of the selected article was analysed.

\section{Workshop 3}

The third workshop focused on paragraph structure, through analysis and discussion of excerpts from the selected articles.

\section{Workshop 4}

The fourth workshop presented the concept of discipline-specific 're-useable language'. Students were shown how to extract re-useable language from well-written text; an example is included below. In the course of doing this, we had a brief discussion on academic integrity and plagiarism, making the point to students that re-using 'common language' with new content in general does not constitute plagiarism. 
Example of model text selected from Hamlin et al. (1996):

'A key to our approach was to conduct petrographic analyses in the context of the stratigraphic framework'.

What is the common (re-useable) language within this excerpt?

'A key to our approach was to conduct analyses in the context of

\section{The homework tasks}

The 'homework tasks' were set to encourage students to practise applying the tools and techniques taught to them during the workshops. Their other purpose was to encourage continual work by the students towards the written assignment, rather than it being left to the last minute. These homework tasks were not assessed, but students were awarded $0.5 \%$ of their overall course mark for submission of each one. In order to further encourage students to engage with these exercises, they were structured such that the students could directly see their relevance to the final assignment task (Table 1). Students were given a date by which they would be provided with feedback by the course lecturer (usually one week from submission), to encourage them to utilise feedback comments in the planning of their written assignment, thereby developing their skills.

Table 1. Details of the Academic Writing Workshops and Homework Tasks.

\begin{tabular}{|l|l|l|}
\hline ALD Workshop Title & Content Detail & Homework Task \\
\hline Introduction and reading & How to examine & 'Translating' an excerpt \\
academic articles & differences between & from the article provided \\
& formal academic and & into more easily- \\
& informal 'spoken' style & understandable, spoken- \\
& language (Halliday 1985) & style language. \\
\hline
\end{tabular}




\begin{tabular}{|l|l|l|}
\hline $\begin{array}{l}\text { De-constructing an article } \\
\text { to identify its structure }\end{array}$ & $\begin{array}{l}\text { How to analyse model text } \\
\text { and imitate it for structure } \\
\text { Deconstructing } \\
\text { assignment task to make a } \\
\text { plan }\end{array}$ & $\begin{array}{l}\text { Putting together the } \\
\text { assignment structure } \\
\text { (given one-month before } \\
\text { the deadline) }\end{array}$ \\
\hline Paragraph Structure & $\begin{array}{l}\text { Identifying common } \\
\text { paragraph structure }\end{array}$ & $\begin{array}{l}\text { Writing a paragraph of the } \\
\text { assignment (any } \\
\text { paragraph they liked; given } \\
\text { three weeks prior to } \\
\text { assignment submission) }\end{array}$ \\
\hline Re-useable language & $\begin{array}{l}\text { How to extract language } \\
\text { from well-written text. } \\
\text { Academic integrity. }\end{array}$ & n/a \\
\hline
\end{tabular}

\section{Assessment of the written assignment}

Several weeks before the submission deadline for this assignment, a handout was provided to students that contained detailed instructions for this assessment task, as well as a simple assessment rubric that showed them how their mark for this assessment would be determined (Table 2). This rubric was designed to emphasise the academic reading and writing skills development aspects of the assignment over the disciplinespecific content. Only $20 \%$ of the assignment mark was based on the relevance and appropriateness of the content; $80 \%$ was based on writing skills that were focused on during the workshops and homework task exercises. The motivation for this from the point of view of the course lecturer was the anticipation that, in getting students to focus on the structure of their writing, they would have to spend time thinking about the content, and thus improve their understanding of this. We also made sure that the assessment rubric reflected our emphasis on attribution of material used rather than on the protocols for citation (e.g. see McGowan, 2005; Chanock, 2008; Magyar, 2012), with 15\% awarded for referencing within the text and 5\% awarded for correct formatting of citations (Table 2). 
Table 2. Simple rubric of assessment criteria provided to students.

\begin{tabular}{|c|c|c|}
\hline $\begin{array}{l}\text { ASPECT OF } \\
\text { ASSIGNMENT }\end{array}$ & $\%$ & Assessment criteria - What you should aim for \\
\hline Introduction & 15 & $\begin{array}{l}\text { Clear, focused statement of the topic. Starts with a broad } \\
\text { introductory sentence, and then progresses to become } \\
\text { more specific. Relates to the title. }\end{array}$ \\
\hline $\begin{array}{l}\text { Structure of assignment } \\
\text { as a whole and structure } \\
\text { of paragraphs. }\end{array}$ & 20 & $\begin{array}{l}\text { Assignment is well structured, with a logical flow of } \\
\text { information. As a result, the assignment is easy to read } \\
\text { and not confusing. } \\
\text { I will provide you with further information on paragraph } \\
\text { structure after Writing Workshop } 3 \text {. }\end{array}$ \\
\hline $\begin{array}{l}\text { Relevance and } \\
\text { appropriateness of } \\
\text { content }\end{array}$ & 20 & $\begin{array}{l}\text { The content is comprehensive and is fully relevant to the } \\
\text { title. Overall quality of the information presented is } \\
\text { outstanding, presenting a comprehensive but concise } \\
\text { review of the topic. Each aspect of the topic that is } \\
\text { mentioned has been explained clearly and the ways in } \\
\text { which this aspect can influence reservoir quality have } \\
\text { been clearly explained. Technical language is } \\
\text { appropriate; concepts are clearly explained. If a figure } \\
\text { has been included, it needs to be of good quality, } \\
\text { relevant to the content and mentioned within the text. }\end{array}$ \\
\hline Sources of Information & 10 & $\begin{array}{l}\text { The minimum expectation for this aspect of the } \\
\text { assignment is that lecture material is referenced as the } \\
\text { source of information presented (P). To obtain a better } \\
\text { mark, you should also look for material from other } \\
\text { sources. One source could be textbooks (C). Another } \\
\text { source could be the articles provided to you during } \\
\text { Writing Workshop } 1 \text { (D). To achieve the maximum } \\
\text { possible marks for this aspect of the assignment (HD), } \\
\text { you should cite at least one published article that you } \\
\text { have researched for yourself. }\end{array}$ \\
\hline $\begin{array}{l}\text { Referencing within the } \\
\text { text }\end{array}$ & 15 & $\begin{array}{l}\text { All sources of information mentioned that are not your } \\
\text { own ideas are cited. }\end{array}$ \\
\hline Conclusion/Summary & 10 & $\begin{array}{l}\text { The content of the assignment is clearly and excellently } \\
\text { summarised. All key aspects of material presented in the } \\
\text { assignment are succinctly described. }\end{array}$ \\
\hline Spelling and Grammar & 5 & Very few minor errors in spelling and grammar. \\
\hline $\begin{array}{l}\text { Formatting of Reference } \\
\text { List }\end{array}$ & 5 & $\begin{array}{l}\text { Accurate and in the correct format, with no more than a } \\
\text { few minor formatting errors. Includes all cited references, } \\
\text { and no references that do not appear within the text. }\end{array}$ \\
\hline
\end{tabular}




\section{Results and observations}

Workshop attendance was lower than lecture attendance, even though workshops were scheduled to run immediately after a course lecture, in the same room, and the distinction between lecture and workshop was not entered separately in the timetable. Twenty-six students were enrolled in the class, of whom two were chronic non-attenders. Typical lecture attendance was between 10 and 20 students, and typical workshop attendance was 10 to 15 students. The number of homework tasks submitted were 11 (task 1), 19 (task 2) and 16 (task 3).

\section{Personal observations}

The selected article used as the principal model text (Hamlin et al., 1996) was initially thought to be too technical and overly long for this group of students. Both of these aspects of the article turned out to be advantageous. When shown the article in the first workshop, students were daunted by its length and technical language. We explained that this was not something we expected them to understand without help, and that we would be taking them through a series of exercises during these workshops that would break it down for them, and give them the tools with which to read and understand it more easily. By the last workshop, following some unsolicited feedback, we sensed that a number of students felt significantly more confident in their abilities to read academic articles. They were probably more proud of their achievements than they would have been if we had presented them with a less apparently complicated or lengthy text. After the last workshop, one student (a native speaker of English and who achieved marks in the top $20 \%$ of the class) acknowledged that she had been 'turned off' by this paper at the start, but that she now felt confident in how to approach reading it.

One student indicated that he found the exercise in the first workshop too simple, which may have disengaged him from future sessions. Nevertheless, some students engaged very well with the first workshop exercise, and homework tasks submitted from this exercise showed that all students who submitted something, including the one that made this comment, had room for improvement. 
The workshops were led by the linguist, with input from the course lecturer. It was immediately apparent that the presence of the course lecturer in these workshops was hugely important, for several reasons:

1. Clarification of discipline-specific terminology, which frequently arose in the middle of a demonstration or exercise.

2. Relating the text from the example article being used in the workshop to the content of the lecture that had just been taught. This had several benefits: engaging students with the content of the reading and writing skills development workshop, highlighting aspects of taught content that the students had not grasped well, and providing an opportunity for students to revise relevant content soon after it had been taught.

3. The provision of a discipline- and industry-specific emphasis on the direct importance of reading and writing abilities to engineers. We believe this resonated more with the students than if the issue had been addressed by the linguist, as someone external to their discipline.

It was noticed immediately by the course lecturer during these workshops that the students were thinking about, and integrating, course content in a way that they, and previous classes of students, had not been doing in the usual lecture and practical classes.

Our approach involved a significant increase to the lecturer workload. Following marking, it was felt that the assessment rubric was too heavily weighted towards some aspects of writing that were relatively easily achieved (Figure 1). The overall distribution of marks awarded were skewed to a higher value than appeared appropriate to the course lecturer. The average mark awarded for the written assignment was 77\%, compared with $70 \%$ for the practical coursework and $69 \%$ for the final exam. Fifteen of the 24 students that completed all three modes of assessment obtained a higher grade for their written assignment than they did for both the more technical coursework submissions and the final exam (six achieved their highest grade in the coursework, and three in the exam). 
Figure 1. Average mark awarded for each of the assessment criteria for the written assignment, presented as a percentage of the total mark available for each aspect. See Table 2 for the rubric. The error bars represent one standard deviation.

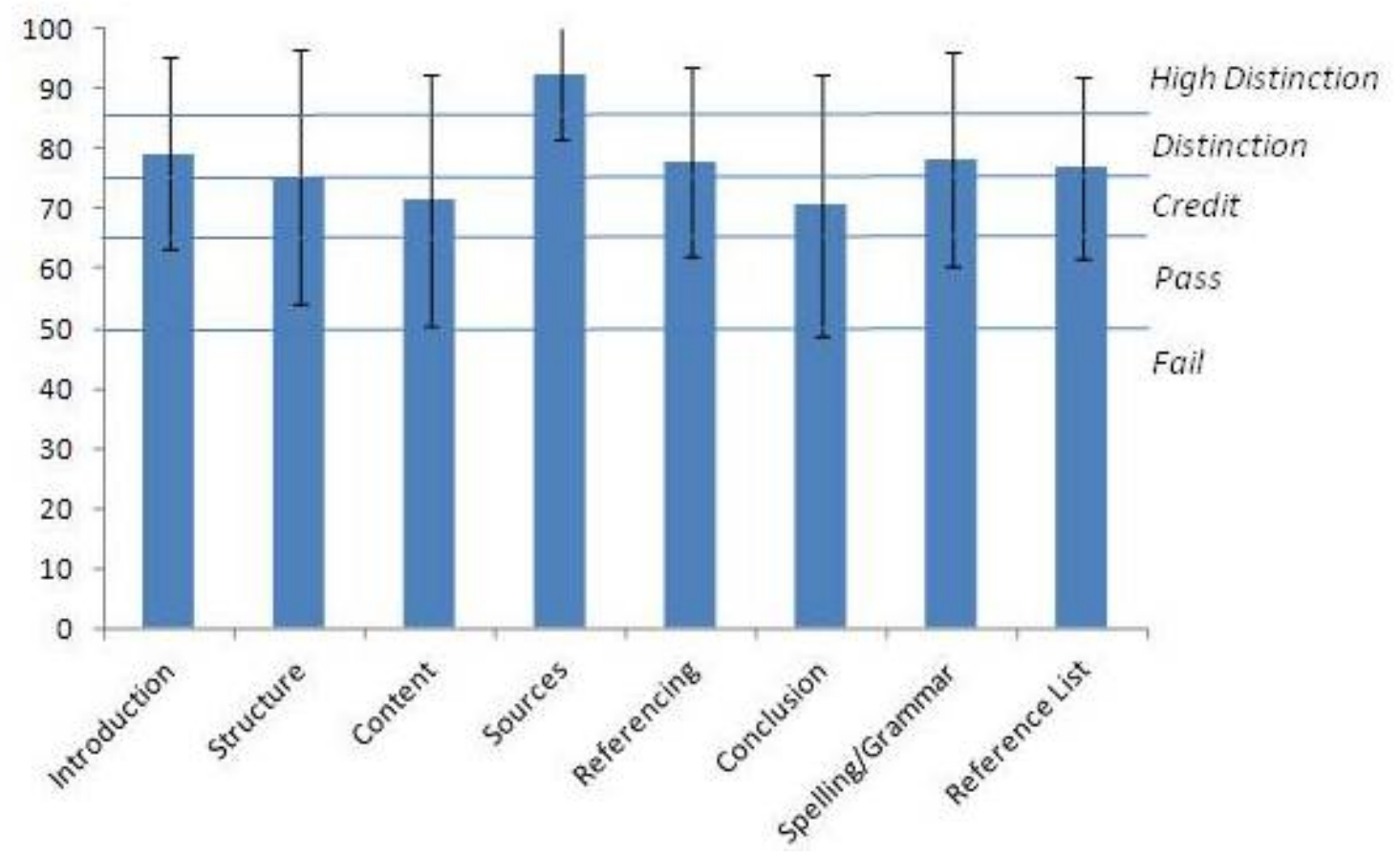

\section{Student survey responses}

Students were asked to complete an anonymous online survey after the first workshop, but only two of them did so. However, when they were asked to complete an anonymous paper-based survey on the day that they submitted the written assignment, nineteen responses were submitted. Of the 19 responses, 11 replied that English was not their first language. Fifteen students believed that the workshops helped them improve their writing skills, and fourteen said that the workshops helped them improve their understanding of course content (Figure 2).

Whilst a significant proportion of the survey respondents stated that English was not their first language, the survey respondents who stated that English was their first language also stated that their reading and writing skills benefited from this approach. During the workshops, we observed the most engaged and responsive students to include both EAL students and students who are native speakers of English. 
Figure 2. Student responses to survey questions (anonymous) regarding their perception that aspects of this approach improved their writing skills and understanding of course content.

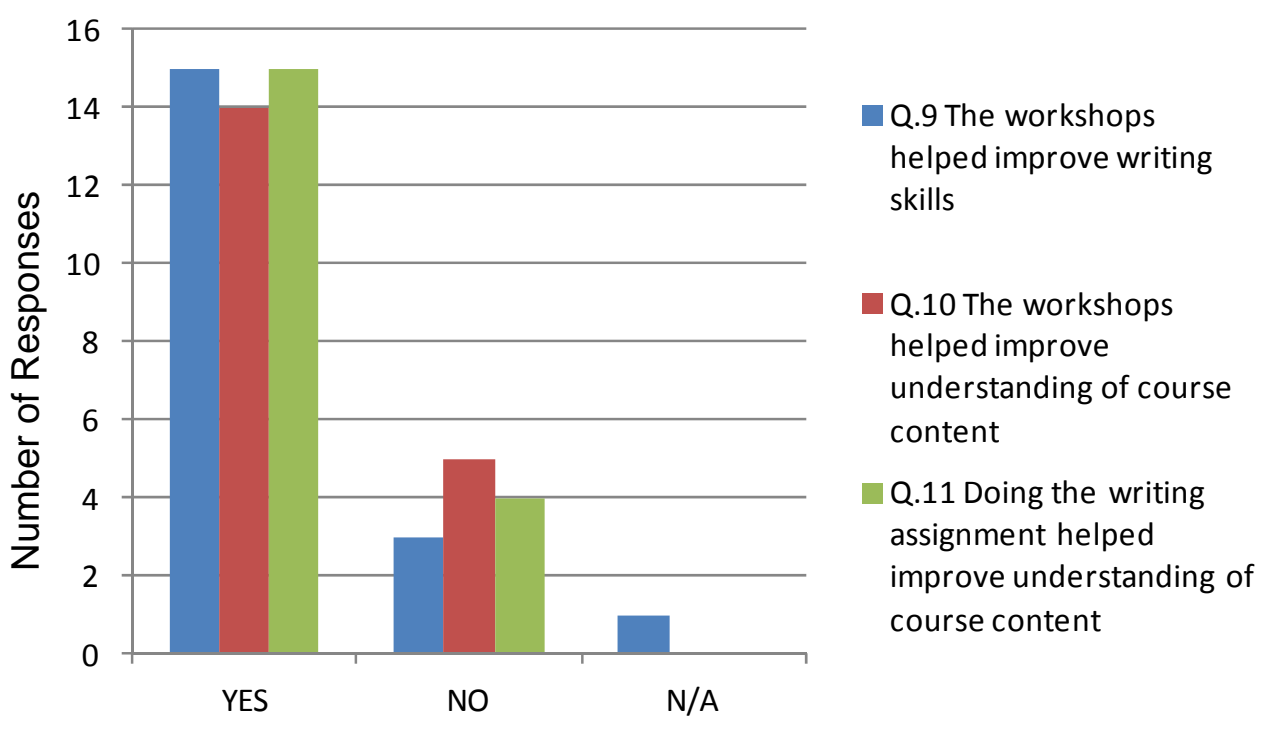

Three students provided written comments: one student commented that they had already begun applying the techniques taught to them through our workshops to other things; one student said they did not think they needed writing tuition like this (and their survey responses showed that they had only attended the first workshop); and one student commented that they found it difficult to write the assignment because they were focusing on how to write rather than on the content.

\section{Evaluation}

Student survey responses and our observations indicate that the four aims of this study were achieved. We provided students with specific tools for reading and writing, and the majority of students believed that the workshops and writing the assignment improved their writing skills (in a way that could be transferred to other subjects and genres) and their engagement with and understanding of the course content. We plan to re-survey this cohort of students at the end of their $3^{\text {rd }}$ and $4^{\text {th }}$ years of study to find out whether they have continued to use the techniques introduced to them during this series of workshops.

Overall, this appeared to be a successful way of motivating these engineering students to think about writing. We are of the opinion that involvement of the course lecturer in the 
writing workshops was important, as was linking this writing assignment directly to both the technical course content and the academic language development workshops and homework tasks, and the careful selection of the model text. However, student participation in workshops and homework tasks was lower than that of student participation in lectures, which is something that will need to be addressed.

\section{Future development}

We will follow this approach again, with some adaptations based on the observations and comments presented above. We will change the focus of the first workshop in order to better challenge the over-confident students, and by this hope to increase their engagement in the workshops. The most significant difference for the running of these workshops during 2012 is that the course lecturer (Amos) will run the workshops on her own, using the material already put together by McGowan in 2011 . This project has resulted in a significant increase in the pedagogical expertise of the lead author (the course lecturer and geoscientist) as a result of this collaboration with the linguist, who is also an academic developer within the Discipline of Higher Education. This was anticipated from the outset and is a key facet of McGowan's proposals for improving student skills in this area. Both authors will continue to adapt and develop this approach for application in other university courses.

A more explicit rubric has been developed that sets out expectations for different levels of achievement (grades) for each of the assessment criteria (Table 3). Making use of an online mechanism for semi-automated feedback provision based on an assessment rubric will be explored as a way of reducing lecturer workload. For those teaching large class sizes, a substantial assignment need not be necessary. We propose that our approach could be adapted such that only a single paragraph is assessed, reducing the marking workload on the course lecturer (as supported by Woods et al., 2000). 


\begin{tabular}{|c|c|c|c|c|c|}
\hline Aspect of thesis & HD & D & c & $\mathrm{p}$ & $\mathrm{F}$ \\
\hline Introduction (15) & $\begin{array}{l}\text { Clear, focused statement of topic. } \\
\text { Relates to the title. Starts with a broad } \\
\text { introductory sentence, and then } \\
\text { progresses to become more specific. }\end{array}$ & $\begin{array}{l}\text { व Clear statement of topic, but lacks } \\
\text { some focus. Relates to the title. Starts } \\
\text { with a broad introductory sentence, } \\
\text { and then progresses to become more } \\
\text { specific. }\end{array}$ & $\begin{array}{l}\text { - Statement of the writing is clear, but } \\
\text { lack overall clarity or focus. Could } \\
\text { have been more clearly or concisely } \\
\text { explained. }\end{array}$ & $\begin{array}{l}\text { Adequate statement of research } \\
\text { problem, but it lacks clarity and } \\
\text { focus. }\end{array}$ & $\begin{array}{l}\text { The introduction does } \\
\text { not adequatelely state the } \\
\text { relevance of this topic or } \\
\text { the content of the } \\
\text { assignment. } \\
\end{array}$ \\
\hline $\begin{array}{l}\text { Structure of } \\
\text { writing (20) }\end{array}$ & $\begin{array}{l}\square \text { Excellent structure of assignment. } \\
\text { Logical flow of information. As result, it is } \\
\text { easy to read. } \\
\text { - Excellent paragraph structure. }\end{array}$ & $\begin{array}{l}\square \text { Very good structure of assignment, } \\
\text { logical. } \\
\square \text { Very good paragraph structure. }\end{array}$ & $\begin{array}{l}\text { The structure is generally good, } \\
\text { mostly logically organised. } \\
\text { Good paragraph structure. }\end{array}$ & $\begin{array}{l}\text { The assignment has an adequate } \\
\text { structure overall, some information } \\
\text { is logically organised. } \\
\text { Contains inappropriate paragraph } \\
\text { breaks, or paragraphs that are far } \\
\text { too long. }\end{array}$ & $\begin{array}{l}\text { A logical basis for the } \\
\text { structure is lacking. } \\
\square \text { Paragraph structure is } \\
\text { inadequate }\end{array}$ \\
\hline Content (25) & $\begin{array}{l}\text { Content is comprehensive, entirely } \\
\text { relevant to the title, of outstanding } \\
\text { quality. Presents a comprehensive yet } \\
\text { concise review of the topic. } \\
\text { Demonstrates originality and } \\
\text { independent thought. } \\
\square \text { Each key content area is explained } \\
\text { clearly, and the ways in which this } \\
\text { content area can influence ereservoir } \\
\text { quality are clearly explained. } \\
\square \text { Figures are of outstanding quality, } \\
\text { relevant to the content, and cited in the } \\
\text { text. Contain full 'stand alone' captions. }\end{array}$ & $\begin{array}{l}\text { Content is comprehensive, entirely } \\
\text { relevant to the title, of outstanding } \\
\text { quality. } \\
\text { Each key content area is explained } \\
\text { clearly, and the ways in which this } \\
\text { content area can influence reservoir } \\
\text { quality is clearly explained. } \\
\text { If figures are included, they are of } \\
\text { very good quality, relevant to the } \\
\text { content, and mentioned in the text. } \\
\text { Contain full 'stand alone' captions. }\end{array}$ & $\begin{array}{l}\square \text { Content is not all linked to the title. } \\
\text { Most of the key content is covered, is } \\
\text { mostly relevant and appropriate to } \\
\text { the topic, though may have some } \\
\text { minor errors or extraneous material. } \\
\text { If figures are included, they are of } \\
\text { good quality and relevant to the } \\
\text { content, but could be improved upon, } \\
\text { either in terms of their content or } \\
\text { presentation. } \\
\text { Sound knowledge of the content and } \\
\text { its relevance to the topic. Some } \\
\text { captions are unclear/incomplete. } \\
\end{array}$ & $\begin{array}{l}\text { Content is adequate, however does } \\
\text { not cover all key aspects of } \\
\text { content. Might include } \\
\text { inappropriate content. } \\
\text { If figures are included, they are of } \\
\text { adequate quality and content, but } \\
\text { could be improved upon in terms of } \\
\text { their rontent and presentation. } \\
\text { Captions are generally } \\
\text { incomplete/unclear. }\end{array}$ & $\begin{array}{l}\text { The content is not } \\
\text { adequate, either } \\
\text { because an insufficient } \\
\text { amount of information } \\
\text { and detail have been } \\
\text { presented, or because } \\
\text { the content included is } \\
\text { not appropriate to the } \\
\text { topic. }\end{array}$ \\
\hline $\begin{array}{l}\text { Sources and } \\
\text { Citation (20) }\end{array}$ & $\begin{array}{l}\text { All sources of information mentioned } \\
\text { that are not your own ideas are cited. } \\
\text { Several peer-reviewed published articles } \\
\text { are cited that you have researched for } \\
\text { yourself. }\end{array}$ & $\begin{array}{l}\square \text { All sources of information mentioned } \\
\text { that are not your onnin ideas are cited. } \\
\text { At least one peer-reviewed published } \\
\text { article is cited that you have } \\
\text { researched for yourself. }\end{array}$ & $\begin{array}{l}\text { Some minor lack of citation (i.e. Not } \\
\text { all information included in the writing } \\
\text { that draws on information sourced } \\
\text { from elsewhere is cited) } \\
\text { One of the model articles provided to } \\
\text { you in the AALL writing workshops is } \\
\text { cited }\end{array}$ & $\begin{array}{l}\text { Frequent lack of citation of the } \\
\text { source of information included } \\
\text { The minimum expectation for this } \\
\text { assignments is that lecture material } \\
\text { is referenced as the source of } \\
\text { information presented. }\end{array}$ & $\begin{array}{l}\square \text { Sources of information } \\
\text { are not cited. }\end{array}$ \\
\hline $\begin{array}{l}\text { Conclusion } \\
\text { (10) }\end{array}$ & $\begin{array}{l}\text { The content is clearly and excellently } \\
\text { summarised. All key aspects of material } \\
\text { presented in the assignment are } \\
\text { succinctly described. }\end{array}$ & $\begin{array}{l}\text { The content is well presented and } \\
\text { summarised. All key aspects of } \\
\text { material presented in the assignment } \\
\text { are described. Generally succinct. }\end{array}$ & $\begin{array}{l}\text { Most key aspects of material } \\
\text { presented in the assignnent are } \\
\text { described. The summary could be } \\
\text { presented more clearly or written } \\
\text { much more succinctly. Some key } \\
\text { aspects may not have been included. }\end{array}$ & $\begin{array}{l}\text { Conclusion is adequate, but does } \\
\text { not summarise the key aspects of } \\
\text { material that have been presented }\end{array}$ & $\begin{array}{l}\text { Inadequate or missing } \\
\text { conclusion, or } \\
\text { conclusion is of very } \\
\text { poor quality. }\end{array}$ \\
\hline $\begin{array}{l}\text { Spelling and } \\
\text { Grammar (5) }\end{array}$ & $\begin{array}{l}\text { No, or very few, minor errors in spelling } \\
\text { or grammar }\end{array}$ & $\begin{array}{l}\text { Very few minor errors in spelling } \\
\text { and/or grammar }\end{array}$ & $\square$ A number of minor errors & $\begin{array}{l}\text { Errors in spelling and/or grammar } \\
\text { are common }\end{array}$ & $\begin{array}{l}\text { Q Pervasive errors in } \\
\text { spelling and grammar }\end{array}$ \\
\hline Reference List (5) & $\begin{array}{l}\text { Accurate and in the correct format, with } \\
\text { no formatting errors. Includes all cited } \\
\text { references, and no references that do } \\
\text { not appear in the text. }\end{array}$ & $\begin{array}{l}\text { Accurate and in the correct format, } \\
\text { with no more than a few minor } \\
\text { formartting errors. Includes all cited } \\
\text { references, and no references that do } \\
\text { not appear in the text. }\end{array}$ & $\begin{array}{l}\text { Mostly accurate (there may be one or } \\
\text { two missing or extra references), in } \\
\text { the correct format, and with few } \\
\text { minor errors. }\end{array}$ & $\begin{array}{l}\text { Adequate, although contains a } \\
\text { number of missing or extra } \\
\text { references, and some } \\
\text { inconsistencies in formatting. }\end{array}$ & $\begin{array}{l}\text { Contains several } \\
\text { references not cited } \\
\text { within the text and } \\
\text { several references cited } \\
\text { in the text are missing. } \\
\text { Inconsistant formatting. }\end{array}$ \\
\hline
\end{tabular}

Table 3. More detailed assessment rubric developed for use in 2012. 
We propose that if the integration of academic language skills development and understanding core content can be demonstrated to improve both facets of student learning and development, and an approach is developed that can be readily applied by course lecturers to enable them to do this, then we anticipate that more STEM academics are likely to engage with the development of academic language skills. A commitment by academics could serve to motivate their students to accept the importance of literacy competence for their undergraduate learning, as preparation for their research writing at Honours level as well as for written communication within their future workplace.

\section{Conclusions}

This paper outlines the development of a new approach for enhancing academic reading and writing skills of engineering students. Observations by the lecturer, linguist and student feedback indicate that it achieved the aims of better developing student writing skills, providing students with tools for academic reading and writing that they can apply in the future, better engaging students with course content, and improving student integration of course content. A series of Academic Language Development workshops was run during lecture time that formed part of their course curriculum, and content focused explicitly on both reading and writing skills, as well as on course content. Our approach draws on genre analysis; students were taught how to 'unpack' densely written academic texts and to use these as models to advance their own writing skills (at the levels of sentences, paragraphs and whole articles). Students were encouraged to complete nonassessed 'homework tasks' following the workshops, for which they received feedback, and which were directly related to student preparation of a substantial and assessed written assignment. Assessment of this assignment focused more on writing skills than on technical content. In a post-completion survey, most students said that the workshops and writing the assignment improved both their writing skills and their understanding of course content. This approach could readily be adapted to different academic disciplines. It is hoped that its integrated nature, with benefits to student understanding of core content, may increase engagement of traditionally resistant students with the development of their academic language skills and encourage the engagement of STEM academics. 


\section{Acknowledgements}

We acknowledge the role of Associate Professor Kogi Naidoo, Coordinator of the University of Adelaide's Academic Staff Development course 'Teaching at University', for providing the productive environment in which this project collaboration was conceived and facilitated. The 2012 assessment rubric draws on aspects of other rubrics that were developed jointly by Kathryn Amos, Mark Tingay and Mary Gonzalez, Australian School of Petroleum.

\section{References}

Ajdukiewicz, J.M. and Lander, R.H. (2010) 'Sandstone reservoir quality prediction: the state of the art', AAPG Bulletin, 94(8), pp. 1083-1091.

Atlay, M. and Harris, R. (2000) 'An institutional approach to developing students' transferable skills', Innovations in Education and Training International, 37(1), pp. 76-81.

Berthouex, P.M. (1996) 'Honing the writing skills of engineers', Journal of Professional Issues in Engineering Education and Practice, 122(3), pp. 107-110.

Biggs, J. (1999) 'What the student does: teaching for enhanced learning', Higher Education Research and Development, 18(1), pp. 57-75.

Cargill, M. and O'Connor, P. (2009) Writing scientific research articles. Strategies and steps. Chichester, UK: Wiley-Blackwell. Available at: http://www.writeresearch.com.au/ (Accessed: 3 March 2010).

Chadha, D. and Nicholls, G. (2006) 'Teaching transferable skills to undergraduate engineering students: recognising the value of embedded and bolt-on approaches', International Journal of Engineering Education, 22(1), pp. 116-122. 
Chanock, K. (2008) 'When students reference plagiarised material - what can we learn (and what can we do) about their understanding of attribution?', International Journal for Educational Integrity, 4(1), pp. 3-16. Available at: http://www.ojs.unisa.edu.au/index.php//JEl/issue/view/48 (Accessed: 25 April 2012).

Cismas, S.C. (2010) 'Educating academic writing skills in Engineering', in Dondon, P. and Martin, O. (eds.) Latest trends on engineering education: Proceedings of the 7th WSEAS International Conference on Engineering. Corfu Island, Greece 22-24 July. WSEAS Press, pp. 247-251.

Cope, B. and Kalantzis, M. (1993) 'How a genre approach to literacy can transform the way literacy is taught', in Cope, B. and Kalantzis, M. (eds.) The powers of literacy: a genre approach to the teaching of writing. London: Falmer Press, pp. 1-21.

Disadvantaged Schools Program (1988) Teaching Factual Writing. A genre-based approach. Sydney. Metropolitan East Region. New South Wales Department of Education.

Drummond, I., Nixon, I. and Wiltshire, J. (1998) 'Personal transferable skills in higher education', Quality Assurance Education, 6(1), pp. 19-27.

Halliday, M.A.K. (1985) Spoken and written language. Burwood, Victoria 3125: Deakin University Press.

Halliday, M.A.K. and Hasan, R. (1985) Language, context, and text: aspects of language in a social-semiotic perspective. Burwood, Victoria 3125: Deakin University Press.

Hamlin, H.S., Dutton, S.P., Seggie, R.J. and Tyler, N. (1996) 'Depositional controls on reservoir properties in a braid-delta sandstone, Tirrawarra Oil Field, South Australia', Association of American Petroleum Geologists Bulletin, 80(2), pp. 139_ 156.

Kemp, I. and Seagraves, L. (1995) 'Transferable skills: can higher education deliver?', Studies in Higher Education, 20(3), pp. 315-328. 
Magyar, A. (2012) 'Plagiarism and attribution: an academic literacies approach?', Journal of Learning Development in Higher Education, Issue 4, March, pp.1-18.

Martin, J.R. (1989) Factual writing: exploring and challenging social reality. Oxford: Oxford University Press.

Martin, J.R. (1997) 'Analysing genre: functional parameters', in Christie, F. and Martin, J. (eds.) Genre and institutions. Social processes in the workplace and school. London and Washington: Cassell, pp. 3-39.

McGowan, U. (2005) 'Does educational integrity mean teaching students NOT to 'use their own words'?', International Journal for Educational Integrity, 1(1), pp. 1-11.

Available at: http://www.ojs.unisa.edu.au/index.php/lJEl/article/view/16/6 (Accessed: 15 April 2012).

McGowan, U. (2008) 'International students: a conceptual framework for dealing with unintentional plagiarism', in Roberts, T.S. (ed.) Student plagiarism in an online world: problems and solutions. Hershey, New York: Information Science Reference, pp. 92-107.

McGowan, U. (2010) 'Re-defining academic teaching in terms of research apprenticeship', in Devlin, M., Nagy, J. and Lichtenberg, A. (eds.) Research and development in higher education: reshaping education, Volume 33. HERDSA, pp. 481-489. Available at: http://www.herdsa.org.au/?page id=1371\#M (Accessed: 15 April 2012).

Mottershead, D. and Suggitt, S. (1996) 'Developing transferable skills: some examples from geomorphology teaching', Journal of Geography in Higher Education, 20(1), pp. 75-82.

Oakley, B., Connert, B. and Allen, K. (1999) 'Incorporating writing skills into the engineering curriculum', $29^{\text {th }}$ ASEE/IEEE Frontiers in Education Conference. San Juan, Puerto Rico 10-13 November. Available at http://fieconference.org/fie99/papers/1071.pdf (Accessed 29 April 2012) 
Pennycook, A. (1996) 'Borrowing others' words: text, ownership memory and plagiarism', TESOL Quarterly, 30(2), pp. 201-230.

Swales, J. (1990) Genre analysis. English in academic research settings. New York: Cambridge University Press.

Ventola, E. (1996) 'Packing and unpacking information in academic texts', in Ventola, E. and Mauranen, A. (eds.) Academic writing. Intercultural and textual issues. Amsterdam and Philadelphia: John Benjamins, pp. 153-194.

Weissberg, R. and Buker, S. (1990) Writing up research. Experimental research report writing for students of English. Englewood Cliffs, NJ: Prentice Hall.

Wheeler, E. and McDonald, R.L. (2000) 'Writing in engineering courses', Journal of Engineering Education, 89(4), pp. 481-486. Available at: http://www.jee.org/2000/october/322.pdf (Accessed: 15 April 2012).

Wingate, U. (2006) 'Doing away with 'study skills”, Teaching in Higher Education, 11(4), pp. 457-469.

Woods, D.R., Felder, R.M., Rugarcia, A. and Stice, J.E. (2000) 'The future of engineering education III. Developing critical skills', Chemical Engineering Education, 34(2), pp. 108-117.

\section{Author details}

Kathryn Amos is a Lecturer at the Australian School of Petroleum (ASP), Faculty of Engineering, Computing and Mathematical Sciences, University of Adelaide. Kathryn teaches courses in Sedimentology and Stratigraphy to students enrolled in engineering and geoscience degree programmes. She leads the Lake Eyre Basin Analogues Research Group and is Programme Co-ordinator for the Honours and MSc (Coursework) degrees in Petroleum Geoscience. Kathryn was awarded a PhD (2004) in the field of sedimentology from the University of East Anglia, UK, and a BSc (Hons) in Environmental Sciences (1999) from the same university. Kathryn 
worked as a research fellow at the University of Leeds (UK), University of New South Wales (UNSE@ADFA, Canberra, Australia) and the University of Adelaide before taking up her current lectureship position in 2009. Kathryn is a clastic sedimentologist with expertise in dryland and sub-marine sedimentology, focusing on the application of scale models and modern analogues for interpreting ancient successions. (kathryn.amos@adelaide.edu.au)

Ursula McGowan is Senior Lecturer, Academic Staff Development in the Discipline of Higher Education at the School of Education, University of Adelaide. She has been responsible for academic staff development, including the support of academic induction for tenured, contract and sessional staff. She is bilingual (GermanEnglish) and is an experienced linguist in core course lecturing (German Language and Literature) and in teaching English as an Additional Language (EAL). Her current research focus is on oral and written language issues for students and staff from language backgrounds other than English. In her recent publications she has developed an approach to minimising students' inadvertent plagiarism by highlighting the research-based nature of undergraduate assignment writing. (ursula.mcgowan@adelaide.edu.au) 